ISSN 1112-9867

Available online at $\quad$ http://www.jfas.info

\title{
INFLUENCE OF TECHNOLOGICAL AND MECHANICAL PROPERTIES RATIO OF NICKEL-BASE HEAT-RESISTANT ALLOY ON ABILITY TO DEEP DRAWING
}

\author{
D. L. Pankratov, I. O. Jigulev, V. V. Shibakov, A. E. Kryukov, R. V. Shibakov
}

Kazan Federal University, Naberezhnye Chelny Institute

Published online: 08 August 2017

\begin{abstract}
One of the conditions ensuring the competitive advantages of a final product is the possibility of carrying out complex, resource-saving technological processes of workpiece shaping from the materials that provide necessary operational properties. In particular, such processes include the deep drawing of products. The advantages of deep drawing are a sufficiently high coefficient of used material, as well as an exceptional possibility of thin-walled deep detail manufacture from sheet blanks of "Gilsa" type. A prerequisite for the use of deep drawing is a series of technological and mechanical properties of material.

The article considers the estimation of possibility use for a deep drawing of nickel alloy ensuring the necessary level of operational properties of a product, first of all - heat resistance. The results of tests are provided evaluating the physical and mechanical properties of GH304 T14992-1994 alloy, as well as test data, on the basis of which they developed the recommendations for deep drawing of products made of nickel alloys.
\end{abstract}

Key words: nickel alloys, sheet stamping, die tooling, anisotropy of properties, deep drawing.

\section{INTRODUCTION}

As the part of competitive import substitution program, Russian machine-building plants have to select the analogues of materials for the manufacture of products with special properties. The technical literature on the calculation of sheet material deformation processes contains mainly the information on the stampability of the most common types of sheet steels: $08 \mathrm{Yu}$, $08 \mathrm{kp}, 10 \mathrm{kp}$ steel.

Author Correspondence, e-mail: krjukoff@mail.ru

doi: http://dx.doi.org/10.4314/jfas.v9i2s.73 
At the same time, there is a need to have information on the properties of newly developed or little-used alloys with special properties.

The aim of this article is to investigate the technological and mechanical properties of GH304 T14992-1994 (the Russian analogue of $\mathrm{KhN} 45 \mathrm{Yu}$ ) and to establish its suitability for deep drawing of an energy engineering product having the required level of operational properties, namely high heat resistance and strength $[1,2]$.

In order to determine the suitability for the extraction of HN45Y alloy, the tests were carried out to determine the following ductility parameters: the relative elongation $\delta$ and constriction $\psi$ along, across and at the angle of $45^{\circ}$ to the rolling direction. In addition, the Poisson's ratio, the normal anisotropy coefficient $R$ and the hardening coefficient $\eta$ were determined $[3,4]$. In the process of plastic deformation, when the grain of sheet material is rolled, an elongation is obtained along the axis of maximum deformation (rolling direction). Thus, polycrystalline metal acquires deformation anisotropy characterized by the dependence of strength and plastic properties from the direction of the preferential orientation of crystals $[5,6]$. This affects the distribution of stress fields and deformations that occur when the parts of a complex shape are stamped, the result of which is the possibility of local thinning of a sheet blank up to the rupture, as well as the development of creases and ears - wave-like protrusions on the edge of a drawn product flange, which causes necessity of their cutting [7.8].

\section{MATERIALS AND METHODS}

The material for the work was represented by the samples of sheet material for the study of technological and mechanical properties, on the basis of which it will be concluded that the material is suitable for deep drawing [9].

The capacity of the material for deep drawing was estimated by the following parameters:

- the ratio of the yield point to the ultimate strength of the material;

- the values of the anisotropy coefficient and the strain hardening index;

- the depth of an extruded spherical well.

\section{TEST RESULTS}

Table 1 shows the strength and the ductility characteristics of KhN45YU alloy obtained during mechanical tensile testing of standard specimens from sheet material (GOST 1170184) 
Table 1. Characteristics of alloy KhN45Yu strength and ductility

\begin{tabular}{|l|l|l|l|l|l|}
\hline \multirow{2}{*}{ Material } & \multicolumn{4}{|l|}{ Mechanical properties } \\
\cline { 2 - 6 } & $\sigma_{\mathrm{B}},(\mathrm{MPA})$ & $\sigma_{02},(\mathrm{MPA})$ & $\delta,(\%)$ & $\psi,(\%)$ & Microhardness, HV \\
\hline HN45Y alloy & $850-890$ & $480-500$ & $28-30$ & $20-22$ & $250-270$ \\
\hline
\end{tabular}

Concerning the yield stress to the ultimate strength, it is possible to determine the "margin" of metal plasticity from the onset of plastic deformation to failure. The material for deep drawing must have a specified ratio of no more than $0.6 \ldots 0.65$. This parameter for the test material makes $0.56 \ldots 0.6$, which characterizes the material as plastic one $[12,13]$.

The anisotropy is estimated by an index-anisotropy coefficient $\bar{R}$ - which is the ratio of the logarithmic deformations along the width $e_{b}$ and the thickness $e_{S}$ of a flat specimen under tension:

$$
\bar{R}=\frac{e_{b}}{e_{S}}=\frac{\ln \left(b_{1} / b_{0}\right)}{\ln \left(S^{s_{1}} / S_{0}\right)},
$$

where $b_{0}$ and $S_{0}$ - the initial width and thickness of a sample, mm;

$b_{1}$ and $S_{1}$ - the width and the thickness of a sample after stretching, $\mathrm{mm}$.

The steels with the indices of anisotropy $\bar{R}=1,2 \ldots 1,7$ and strain hardening index $\mathrm{n}>0.2$ at uniform elongation $\delta_{p}>20 \%$. The index of strain hardening is the true (logarithmic) deformation in the stretch area.

The tests were carried out with the automated compilation of protocols. The test results are shown in Table 2.

Table 2. Anisotropy indices of sample material

\begin{tabular}{|l|l|l|l|}
\hline $\begin{array}{l}\text { Sample } \\
\text { № }\end{array}$ & $\begin{array}{l}\text { Rolling } \\
\text { direction }\end{array}$ & $\begin{array}{l}\text { Anisotropy } \\
\text { index }\end{array}$ & $\begin{array}{l}\text { Hardening } \\
\text { index }\end{array}$ \\
\hline 1 & $0^{\circ}$ & 0,67 & 0,4 \\
\hline 2 & $0^{\circ}$ & 0,87 & 0,25 \\
\hline 3 & $90^{\circ}$ & 2,12 & 0,2 \\
\hline 4 & $90^{\circ}$ & 1,08 & 0,26 \\
\hline 5 & $45^{\circ}$ & 1,02 & 0,29 \\
\hline 6 & $45^{\circ}$ & 0,99 & 0,27 \\
\hline
\end{tabular}


A good metal stampability is observed with the anisotropy coefficient of at least 1.2..1.7 and the strain hardening index of more than 0.2. According to these parameters the tested alloy $\mathrm{R}$ $(0,67-2,12)$ and $n(0,2-0,4)$ is suitable for deep drawing.

The determination of technological properties was carried out by the method of Eriksen GOST 10510-80. This standard regulates the test for a spherical well extrusion in sheet materials with the thickness of 0.1 to $2.0 \mathrm{~mm}$ at the temperature of $(20+15-10){ }^{\circ} \mathrm{C}[10,11]$.

The method consists in the pressing of a spherical punch into the sample, which is pressed under the action of the pressing force between the matrix and the pressed ring, which is carried out prior to the development of a through crack on an extruded hole, after which the depth of the hole is determined.

In order to determine the technological properties of the alloy, the samples of 90x90 $\mathrm{mm}$ were used.

According to the blank test results, it is possible to draw the following conclusions:

1. The height of the hole is $11 \mathrm{~mm}$, which indicates that the sheet material is sufficient for sheet ductility stretching.

2. The shape of rupture indicates the metal ability to plastic deformations by thickness.

3. Minor material thinning at the edge of the rupture and its roughness indicates a significant hardening of the material.

The obtained data characterize the studied alloy as an acceptable one for deep drawing, although there is a risk of discontinuities due to an insufficient value of the anisotropy coefficient [14].

\section{CONCLUSIONS}

1. Due to the high hardenability and alloy ratio anisotropy close to the critical value it is necessary to increase the gap between the working parts of a stamp to reduce the likelihood of destruction.

2. At a multi-transitional deep drawing, it is necessary to use interoperational annealing.

3. An effective lubricant should be used to reduce the coefficient of friction and deformation force and increase the durability of the die working parts.

\section{SUMMARY}

The analysis of nickel alloy thickness variation shows that the studied high-temperature alloy tends to thicken more intensively than low-carbon steel, and at places uncharacteristic for steel semi-finished products. If the most common defect in steel transitions is bottom 
separation, then the alloy is characterized by ruptures and scratches, which indicates its propensity to thickening.

\section{ACKNOWLEDGEMENTS}

The work is performed according to the Russian Government Program of Competitive Growth of Kazan Federal University.

\section{REFERENCES}

1. Shishlyaev V.N. Non-ferrous alloys. Tutorial. - Perm: Perm State Technical University, 2009. - 235 p. - ISBN 978-5-398-00162-4.

2. Concise Metals Engineering Data Book Joseph R. Davis. ISBN-13: 978-0-87170-606-

5. Copyright 2007

3. Gun G.Ya. Theoretical foundations of metal processing by pressure. (Theory of plasticity). M.: Metallurgy, 1980. - $456 \mathrm{p}$.

4. Davies J.R. (Ed.) Nickel, Cobalt, and Their Alloys (ASM Specialty Handbook) ASM International, 2000. 421 p. ISBN:0-87170-685-7

5. Bobylev A.V. Mechanical and technological properties of metals. Reference book: 2nd ed., revised and added. - Moscow: Metallurgy, 1987. - 208 p.

6. SAE J1099 Revised JUN1998 Technical Report on Low Cycle Fatigue Properties Ferrous and Non-Ferrous Materials 2002-08-13

7. Fu M.W. Design and Development of Metal-Forming Processes and Products Aided by Finite Element Simulation Springer International Publishing AG, 2017. — 258 p. (Engineering Materials and Processes) — ISBN 9783319464626.

8. Tschätsch H., Koth A. Metal Forming Practise: Processes - Machines - Tools. Springer, 2006. 415 p. ISBN:3540332162

9. Kargin V.R., Kargin B.V. Experimental study of deformation processes during pressure treatment. Manual for the lecture course. - Samara: Samara state aerospace university. 2010. - 49 p.

10. Borovik P.V. Usatyuk D.A. New approaches to mathematical modeling of pressure treatment technological processes: Monograph. Monograph. - Alchevsk: DonDTU, 2011. 299 p.

11. Wagoner R.H., Chenot J.L. Metal forming analysis. Cambridge, Cambridge University Press, 2001. - 376 p. 
12. Hosford W.F. Fundamentals of Engineering Plasticity. Cambridge University Press, New York, 2013. VIII, 267 p. - ISBN 978-1-107-03755-7 (hardback).

13. Gubkin S.I. Plastic deformation of metals. Volume 1. Physical and mechanical basis of plastic deformation. Moscow: Metallurgizdat, 1961. - 376 p.

14. Hingole Rahulkumar Shivajirao. Advances in Metal Forming: Expert System for Metal Forming. Springer Berlin Heidelberg, 2015. — 126 p. — ISBN 9783662444979

\section{How to cite this article:}

Pankratov D L, Jigulev O I, Shibakov V V, Kryukov A E, Shibakov R V. Influence of technological and mechanical properties ratio of nickel-base heat-resistant alloy on ability to deep drawing. J. Fundam. Appl. Sci., 2017, 9(2S), 984-989. 